\title{
Sorocea carautana (Moraceae): A New Species from Southeastern Brazil
}

\author{
M. D. M. Vianna Filho
}

Museu Nacional/Universidade Federal do Rio de Janeiro, Quinta da Boa Vista s/n, São Cristóvão, 20940-040 Rio de Janeiro, Brazil. marceloviannafilho@gmail.com

\section{T. T. Carrijo}

Instituto de Pesquisas Jardim Botânico do Rio de Janeiro, Rua Pacheco Leão 915, Jardim Botânico, 22460-030 Rio de Janeiro, Brazil

\author{
S. Romaniuc Neto \\ Instituto de Botânica de São Paulo, Av. Miguel Estéfano 3687, Água Funda, \\ 04301-902 São Paulo, Brazil
}

Abstract. A new species of Sorocea A. SaintHilaire, S. carautana M. D. M. Vianna, Carrijo \& Romaniuc (Moraceae s. str.), was discovered in the hills of southern Rio de Janeiro in the vicinity of Paraty. The new species resembles $S$. hilarii Gaudichaud by the similar shape of the leaves, but is clearly distinguished by its longer pistillate pedicel. This new species is endemic to the Atlantic Forest and is threatened due to its restricted geographic area of occurrence.

Resumo. Uma nova espécie de Sorocea A. SaintHilaire, S. carautana M. D. M. Vianna, Carrijo \& Romaniuc (Moraceae s. str.), foi descoberta nos maciços do sul do estado do Rio de Janeiro, no município de Paraty. A nova espécie assemelha-se a S. hilarii Gaudichaud pela forma das folhas, porém é claramente distinta pelo comprimento das inflorescências pediceladas. A nova espécie é endêmica da Floresta Atlântica, e encontra-se ameaçada devido a sua distribuição geográfica restrita.

Key words: Brazil, IUCN Red List, Moraceae, Rio de Janeiro, Sorocea.

Sorocea A. Saint-Hilaire is an exclusively Neotropical genus, and its range extends from Argentina to Mexico. The genus contains around 25 species (Romaniuc Neto, 1998) and is principally characterized by dioecious trees or shrubs. Recent treatments of Sorocea have been offered by Burger et al. (1962), Romaniuc Neto (1998, 1999), and Berg (2001). This last author recognized a species group comprising taxa with a spinulose dentate leaf margin as somewhat distinct from the rest of the genus. The new species belongs to this complex, and its characters are described and illustrated here.
Sorocea carautana M. D. M. Vianna, Carrijo \& Romaniuc, sp. nov. TYPE: Brazil. Rio de Janeiro: Paraty, APA do Cairuçu, Morro do Carrapato, $23^{\circ} 01^{\prime} \mathrm{S}, 44^{\circ} 03^{\prime} \mathrm{W}, 150 \mathrm{~m}, 9$ Dec. 1993, R. Marquete 1405 (holotype, RB; isotype, US). Figure 1.

Haec species quoad foliorum formam ad Soroceam hilarii Gaudichaud proxime accedit, sed ab ea floris feminei pedicello in fructu usque ad $1.7-3.2 \mathrm{~cm}$ elongata et foliis margine integris vel paucispinulosis differt.

Shrub or tree, 7-10 m tall, bark smooth, gray to brownish; leafy twigs $1-4 \mathrm{~mm}$ diam., sparsely puberulent or glabrous, striate; lenticels conspicuous; leaf scars plane. Leaf lamina oblong to lanceolate, 8.7$12.5 \times 2.2-3 \mathrm{~cm}$, slightly unequal, coriaceous, discolorous, apex caudate, acumen not spinulose, base asymmetric, acute to obtuse, margin usually entire, sometimes with few spines; adaxial blade surface glabrous, shiny, abaxial surface sparsely puberulent, opaque; leaf venation brochidodromous, impressed on the midrib adaxially, prominent abaxially, lateral veins in 8 to 13 pairs, tertiary venation mostly reticulate; petiole $5-8 \times 0.7-1.5 \mathrm{~mm}$, puberulent; stipules 2-4 mm, puberulent to glabrous, caducous. Staminate inflorescences unknown. Pistillate inflorescences racemose, 10 to 13 flowers per inflorescence, $5.5-8.5 \mathrm{~cm}$, rachis puberulent, carnose; peduncle $3.5-4.5 \mathrm{~cm}$, puberulent. Pistillate flowers 1.2-1.5 mm, upper perianth with a cupuliform ring, sparsely hispidulous, the lower portion mostly densely hispidulous; stigma bifurcate, finely papillate; pedicel 1-1.2 cm, sparsely puberulent to hispidulous, swollen and red in fruit. Fruiting perianth ovoid, 0.5$1 \mathrm{~cm}$, surface smooth, sparsely puberulent, red to black; pedicel elongating to $1.7-3.2 \mathrm{~cm}$, sparsely puberulent to almost glabrous. 


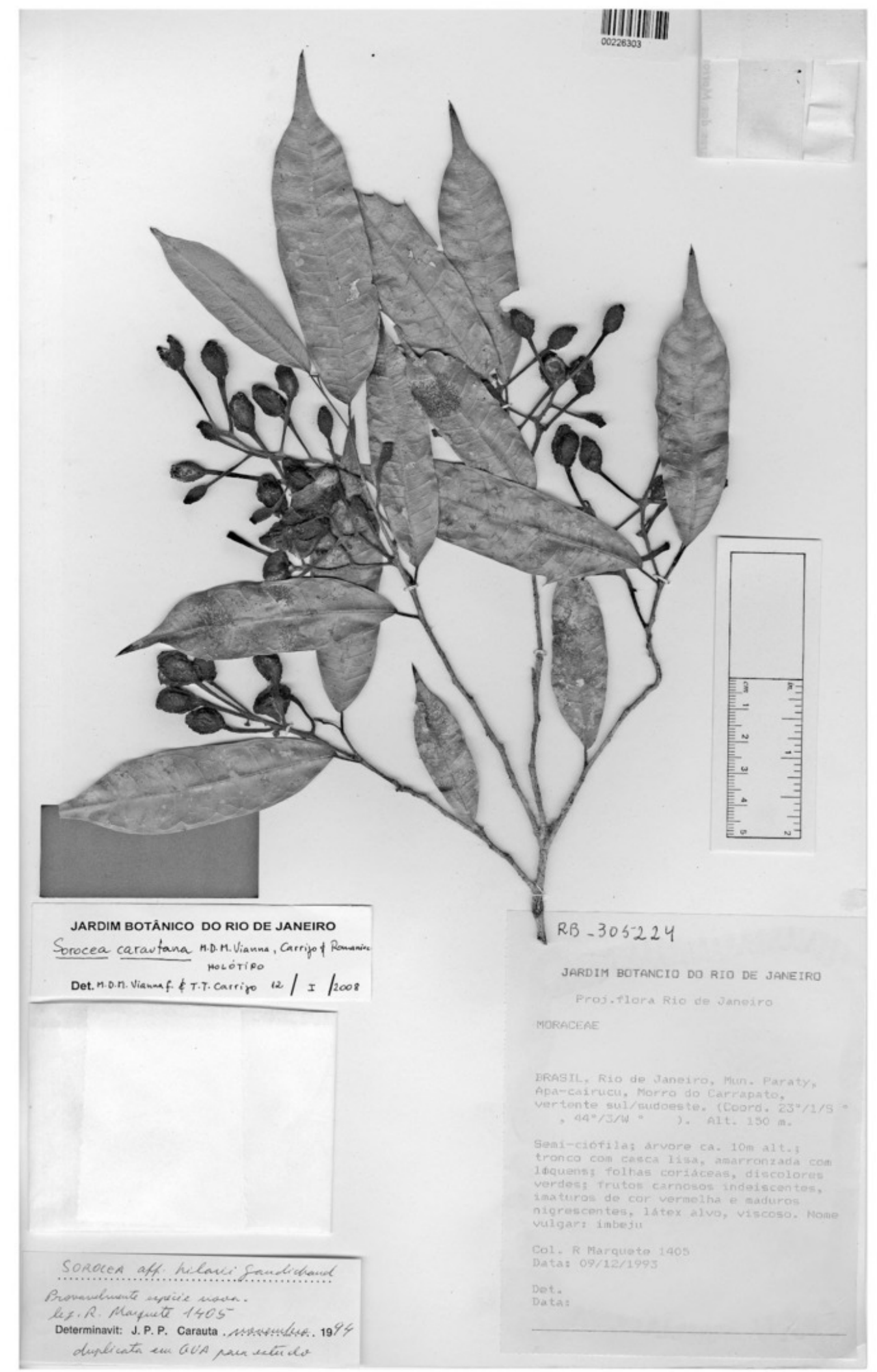

Figure 1. Holotype specimen of Sorocea carautana M. D. M. Vianna, Carrijo \& Romaniuc (R. Marquete 1405, RB).

Distribution and habitat. The new species is restricted to the coastal region of Rio de Janeiro State and is known only from the Environmental Protection Area of Cairuçu, in tropical humid forest of the Serra do Mar from elevations of $150-300 \mathrm{~m}\left(23^{\circ} 10^{\prime}-23^{\circ} 23^{\prime} \mathrm{S}, 44^{\circ} 30^{\prime}-44^{\circ} 51^{\prime} \mathrm{W}\right)$.
IUCN Red List category. According to IUCN Red List criteria (IUCN, 2001), this species is considered Critically Endangered (CR Bla) based on its area of occupancy estimated at less than $100 \mathrm{~km}^{2}$. The new species is known only from Paraty municipality, Rio 
de Janeiro State, where the population is sparsely distributed in the undergrowth of humid forest.

Etymology. The specific epithet carautana was chosen to honor Pedro Carauta, who first recognized this species as possibly new.

Discussion. Sorocea carautana belongs to Sorocea subgen. Sorocea based on the long internodes in the leaf stems, plane leaf scars, inconspicuous axillary buds, distinctly racemose inflorescences (or spicate elsewhere in the subgenus), and bracts that range from subcoriaceous to coriaceous. The new species resembles $S$. hilarii Gaudichaud by the similar shape of the leaves, but is clearly distinguished by the fruiting perianth pedicel length $(1.7-3.2 \mathrm{~cm}$ vs. to $1.2 \mathrm{~cm}$ in S. hilarii).

Additional field data show that Sorocea carautana has smooth bark, a discolorous leaf blade, reddish pistillate peduncles, and nigrescent fruiting perianths. These observations are supported from field data on labels.

Paratypes. BRAZIL. Rio de Janeiro: Paraty, Laranjeiras, estrada nova para Praia do Sono, 8 Dec. 1993, $R$. Marquete 1369 (RB); Paraty, Km 165, Rio-Santos, Faz. São Roque, 13 Dec. 1988, M. Nadruz 455 (RB); Paraty, Saco de Mamanguá, 27 Apr. 1993, R. Marquete 855 (RB); Paraty, Alagado Olaria, APA-Cairuçu, 16 Mar. 1993, M. C. Marques
329 (RB); Paraty, APA-Cairuçu, Morro do Carrapato, 9 Dec. 1993, R. Marquete 1405 (RB); Paraty, 11 May 1994, $R$. Marquete 1784 (RB).

Acknowledgments. The authors are grateful to Jorge Pedro Pereira Carauta for correcting the Latin diagnosis.

\section{Literature Cited}

Berg, C. C. 2001. Moreae, Artocarpae, and Dorstenia (Moraceae). Pp. 103-105 in Fl. Neotrop. Monogr. 83. New York Botanical Garden, Bronx.

Burger, W. C., J. Lanjouw \& J. G. W. Boer. 1962. The genus Sorocea A. St.-Hil. (Moraceae). Acta Bot. Neerl. 11: 428-477.

IUCN. 2001. IUCN Red List Categories and Criteria, Version 3.1. Prepared by the IUCN Species Survival Commission. IUCN, Gland, Switzerland, and Cambridge, United Kingdom.

Romaniuc Neto, S. 1998. Biodiversity and speciation in the south of Brazil and the basin of the Parana River: Influences in the Sorocea A. St-Hil. (Moraceae) genus species complex. Compt. Rend. Acad. Sci. Ser. IIA, Earth Planet. Sci. 327(10): 669-675.

- 1999. Taxonomie et Biogéographie des genres Sorocea A. St.-Hil., Clarisia Ruiz \& Pavón et Trophis P. Browne (Moraceae-Urticales): Mise en évidence de centres d'endémisme et de zones à protéger au Brésil. Thesis, Muséum national d'Histoire naturelle, Paris. 


\section{$2 \mathrm{BHL}$ Biodiversity Heritage Library}

Vianna Filho, Marcelo Dias Machado, Carrijo, Tatiana Tavares, and Romaniuc-Neto, Sergio. 2009. "Sorocea carautana (Moraceae): A New Species from Southeastern Brazil." Novon a journal of botanical nomenclature from the Missouri Botanical Garden 19, 549-551.

View This Item Online: https://www.biodiversitylibrary.org/item/124658

Permalink: https://www.biodiversitylibrary.org/partpdf/121965

\section{Holding Institution}

Missouri Botanical Garden, Peter H. Raven Library

\section{Sponsored by}

Missouri Botanical Garden

\section{Copyright \& Reuse}

Copyright Status: Permission to digitize granted by rights holder Rights: https://www.biodiversitylibrary.org/permissions

This document was created from content at the Biodiversity Heritage Library, the world's largest open access digital library for biodiversity literature and archives. Visit BHL at https://www.biodiversitylibrary.org. 